\title{
SODIUM IN PRECIPITATION IN A BEECH FOREST ECOSYSTEM IN THE KREMNICKÉ VRCHY MTS (WESTERN CARPATHIANS)
}

\author{
MARGITA DUBOVÁ
}

Institute of Forest Ecology, Slovak Academy of Sciences, Štúrova 2, 96053 Zvolen, Slovak Republic; e-mail: dubova@savzv.sk

\begin{abstract}
Dubová M.: Sodium in precipitation in a beech forest ecosystem in the Kremnické vrchy Mts (Western Carpathians). Ekológia (Bratislava), Vol. 33, No. 1, p. 36-47, 2014.

We present data on sodium amounts reaching the forest soil surface at the Beech Ecological Experimental Site Kremnické vrchy Mts (Western Carpathians). Sodium concentration and deposition were determined in precipitation and throughfall sampled from study plots. The mean annual sodium concentrations obtained on the two plots (CC - clear cut, $\mathrm{C}$ - control) were 0.16 (CC) and $0.19 \mathrm{mg} \mathrm{l}^{-1}(\mathrm{C})$. The values were the lowest among the base cations in precipitation. The trends in spring and annual concentrations were similar, in the 10th year after the intervention, identical. The possible cause is interception of precipitation in the stand and the ions tendency to absorb by beech leaf tissues. This may cause interception of precipitation in the stand and the tendency of beech leaf tissue to absorb sodium ions. Also, the mechanism driving the ion exchange between $\mathrm{K}^{+}$and $\mathrm{Na}^{+}$may cause lower sodium content in throughfall. On both plots, the sodium concentration in spring was somewhat higher than in other seasons of the other year: 0.04-0.42 (CC) and $0.07-0.76 \mathrm{mg} \mathrm{l}^{-1}(\mathrm{C})$. The trends of spring sodium concentration and deposition on $\mathrm{C}$ were decreasing. Plot CC in spring was the only case showing an increasing trend. The spring trends evidently reflected the fact that 10-12 years after the cutting intervention, natural regeneration and growth of beech stand occurred on both the plots. Moreover, the mean winter and summer sodium deposition on both plots was low $(0.02 \mathrm{~kg})$, showing a decreasing trend. The autumnal deposition was $0.5 \mathrm{~kg}(\mathrm{CC})$ and $0.3 \mathrm{~kg} \mathrm{ha}^{-1}(\mathrm{C})$. The total annual sodium amount reaching the forest soil surface was lower on $\mathrm{C}(0.9 \mathrm{~kg})$ than on CC $\left(1.2 \mathrm{~kg} \mathrm{ha}^{-1} \mathrm{year}^{-1}\right)$. The crown impact coefficient (CIC), the deposition ratio between the plots C:CC, values were 0.6 (spring, autumn), 1.0 (winter, summer) and 0.8 (year). There was no manifested presence of sodium sources of either natural or anthropogenic origin. All the obtained values are low and may be considered as background. They indicate that the Beech Experimental Ecological Site is ecologically clean.
\end{abstract}

Key words: sodium deposition, precipitation, throughfall, beech ecosystem.

\section{Introduction}

Sodium is an abundant element in the earth's crust. Its percentage $(2.8 \%)$ is more than that of potassium (2.6\%) and magnesium (2.1\%). The range of sodium content in soil is $0.5-1.4 \%$ (Bublinec, Mihálik, 1997), with the lower value being more frequent in soils formed from carbonates and the upper value in soils from alumino-silicates. Among rocks, those very rich 
in sodium are feldspars, primarily albite $\left(6-11 \% \mathrm{Na}_{2} \mathrm{O}\right)$. In nature, sodium can be generated by cation exchange between calcium $\left(\mathrm{Ca}^{2+}\right)$ and sodium $\left(\mathrm{Na}^{+}\right)$if water contacts certain clay minerals. Sodium is released into water by weathering of some alumino-silicates, in which it occurs as a univalent cation, but can also product ionic associates It occurs in them as anivalent cation, but can also form ionic associates (grouping several sodium ions) (Noskovič, 2010). Sodium never occurs alone in nature; it is only embedded in compounds, most frequently as sodium chloride $(\mathrm{NaCl})$ - the primary natural resource of sodium. Sodium salts are easily soluble in water and sodium chloride is an inseparable component of natural waters (Remy, 1961). As for its quantity in atmospheric precipitation, sodium is generally the fourth after potassium, calcium and magnesium (Bublinec et al., 1998). Despite its lower presence in precipitation water, it acts, with other base cations $\left(\mathrm{Ca}^{2+}, \mathrm{Mg}^{2+}, \mathrm{K}^{+}\right)$, in neutralising acid precipitation in forest ecosystems.

In phytochemistry, sodium is neither an essential nutrient nor an irreplaceable trace element (Nováček, 1986). Its average amount in woody plant biomass ranges within 30-100 ppm (Bublinec, 1992, 1994). Sodium is especially important for animals. More than twothirds of the total amount of this element occurs in animal body liquids; only one-third is bound in mineral compounds in bone tissues.

Base cations $\left(\mathrm{Ca}^{2+}, \mathrm{Mg}^{2+}, \mathrm{K}^{+}\right.$and $\left.\mathrm{Na}^{+}\right)$represent a significant part of deposition delivered to the earth's surface from the atmosphere. Unlike sulphur and nitrogen compounds, the first ones do not occur in the gaseous phase. Sodium, together with other base cations, is deposited in wet and in dry way. Wet deposition means delivery of base cations solved dissolved mainly in rain water, snow and mist drops. Dry deposition means transport of base cations in the form of large airborne particulates and soft aerosols. Among the particulates, sodium and calcium ions are generally dominant participating in the total cation flow up to $70 \%$ and more, with magnesium and potassium ions representing less than $15 \%$ of the total. In soft aerosols, the presence of sodium and calcium may reach $65 \%$ or more, while the sodium content may be $35 \%$. The dry deposition of base cations consists of much less fine aerosols than coarse particles. The contribution of soft aerosols is about $10 \%$ or less; the remaining being represented by airborne particulates. The large particulates enter the forest ecosystems generally by sedimentation and the soft aerosols by turbulent mixing and diffusion through the stand's crown canopy (Ragsdale et al., 1992).

In maritime areas, sodium and chlorides in rainwater originate mainly in marine salt $(\mathrm{NaCl})$. In maritime areas, sea salt $(\mathrm{NaCl})$ is a major contributor of sodium and chloride in precipitation. In the inland, the rainfall chemistry is influenced by a wide range of natural and anthropogenic sources (weathering mineral dust, flying ash, anthropogenic emissions, leaching and flashing from leaves and vegetation). Sodium is associated with some problems: with winter de-icing salts, it may enter the living environment. Another anthropogenic sodium source is wastewater. From the viewpoint of environmental hygiene, sodium in water is not important.

The ICP Forests (Integrated Cooperative Programme on Assessment and Monitoring of Air Pollution Effects on Forests) defines measuring of atmospheric deposition of nutrients and pollutants as a critical issue. The focus is put on measuring and monitoring the influence of polluted air on forest ecosystems. For studying the long-term influence of natural and an- 
thropogenic sources on forest ecosystems, the throughfall method has been recommended working with parallel sampling of throughfall in forest stand and of bulk precipitation in open area near the forest (Thimonier et al., 2007, 2008).

Tree crowns in forest stands are a huge recipient of atmospheric deposition. Interaction between atmospheric precipitation and the tree crowns alternates the precipitation chemistry (Parker, 1983; Lovett et al., 1985). This process is an important component of the nutrient cycle (Bublinec, 1991a, 1999). A part of atmospheric precipitation does not reach the forest soil surface directly. By passing through the tree crowns, it is transformed both physically and chemically (Bublinec, Kukla, 1994). The chemical composition of the throughfall is different from the associated atmospheric precipitation (Bublinec, 1993). In tree crowns, ion exchange takes place, together with dissolving and washing off the substances deposed and aerosols caught on the surface of the leaves, twigs and branches. Leaching from the leaf and branch tissues is also possible (Bublinec, 1994). The amount of washed off, dissolved and leached sodium depends on the stand species composition, meteorological conditions, season, as well as on the precipitation amount entering the forest ecosystem (Parker, 1983; Lovett et al., 1985). Physical and chemical properties of the throughfall are controlled by a range of factors, such as the stand type and age and health condition of trees. Beech stands respond to the influence of atmospheric deposition less sensitively than spruce stands. Beech trees show more resistance, as they are not exposed to deposition in the dormant season, unlike spruce trees loaded with deposed substances over the whole year (Polkowska et al., 2005).

\section{Material and methods}

The research was carried out on five study plots of the Beech Experimental Ecological Site (BEES) of the Institute of Forest Ecology (IFE) in Zvolen. The plot series was established in the year 1986, in the Kremnické vrchy Mts ( $\varphi$ $=48^{\circ} 38^{\prime \prime} \mathrm{N}, \lambda=19^{\circ} 04^{\prime \prime} \mathrm{E}$ ) belonging to the Western Carpathian region. The series is situated in the upper part of the catchment area of the mountain stream Kováčovský potok. The stream is considered as ecologically unpolluted. By a cutting intervention (February 1989), five model plots were obtained with the following density values: 0.0 - clear cut (CC), 0.3 - heavy intervention (HI), 0.5 - medium intervention (MI), 0.7 - light intervention (LI) and 0.9 control (C). The BEES is located on a mostly west-facing slope with an inclination of $15^{\circ}$, at an altitude of 480-510 $\mathrm{m}$ a.s.l. The slope is covered with a forest stand aged $80-110$ years, with clearly dominant beech (Fagus sylvatica $\mathrm{L}$.) trees, and an average stand height of $28 \mathrm{~m}$. The bulk precipitation and throughfall have been sampled continually, since the series establishment, after each precipitation event from all the plots. The samples are analysed in the laboratories of the IFE. The concentration of sodium ions is determined by atomic emission spectrophotometry by burning airacetylene at a wavelength of $589.0 \mathrm{~nm}$, with using a sodium hollow cathode lamp. More data on the experimental site and precipitation sampling can be found in the works of Bublinec, Dubová $(1989,1993)$; Kellerová, Dubová (2002); Barna (2004) and Janík et al. (2011).

\section{Results and discussion}

The primary focus of the research performed on BEES study plots is on the bio-geochemical material cycles (nutrients and pollutants) in forest ecosystems (Bublinec et al., 2005). Besides the acid substances entering the forest stand from atmospheric deposition, base cations were also studied $\left(\mathrm{Ca}^{2+}, \mathrm{Mg}^{2+}, \mathrm{K}^{+}\right.$and $\left.\mathrm{Na}^{+}\right)$. The research results for the first three cations have been published in our former works (Bublinec, Dubová, 1993; Bublinec, 1996; Dubová, Bublinec, 2002, 2006). In this contribution, we present data on sodium concentration and deposition 
for two study plots (CC - clear cut area and C - control) in the BEES, obtained across 12 years after the intervention. The aim was to assess the amount of sodium entering the beech stand and reaching the forest soil. For beech, throughfall is supposed negligible uptake and leaching of sodium ions. In throughfall beech stand is supposed negligible receiving and leaching of sodium ions.

Sodium deposition is calculated from precipitation totals $(\mathrm{mm})$ and sodium concentration ( $\left.\mathrm{mg} \mathrm{l}^{-1}\right)$ measured in the sampled water (bulk precipitation and throughfall). It is given in $\mathrm{kg} \mathrm{Na}^{+}$per one hectare per year or season. The annual precipitation totals $(\mathrm{mm})$ measured on the two beech study plots are illustrated in Fig. 1 . The precipitation totals on $\mathrm{C}$ are lower

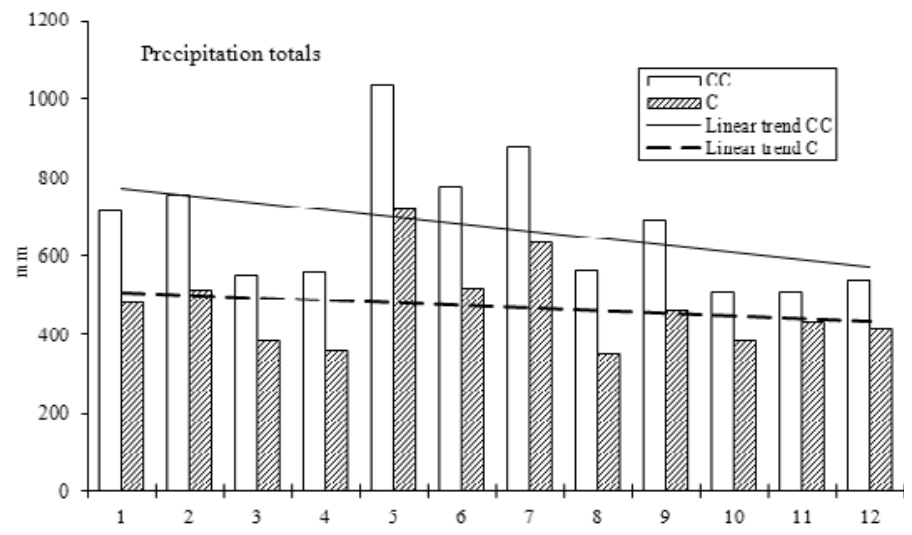

Fig. 1. Annual precipitation totals ( $\mathrm{mm}$ ) and trends on BEES plots CC (clear cut) and C (control) over 12-year study period.

than on CC. The total annual precipitation trends show a moderate decline on both plots, which is also expressed by negative slope values (b) in the linear regression equation for CC $(y=-17.9220 x+787.92)$ as well as for $\mathrm{C}(\mathrm{y}=-6.7381 \mathrm{x}+513.71)$. The CC shows a coefficient of reliability $\mathrm{R}^{2}=0.1502$ and a regression coefficient $\mathrm{R}=0.3876$; the corresponding values for $C$ are lower $\left(R^{2}=0.0466 ; R=0.2159\right)$. The annual precipitation totals across the 12-year study period ranged from 510 to $1040 \mathrm{~mm}$ (arithmetical mean $670 \mathrm{~mm}$ ) on CC and from 350 to $720 \mathrm{~mm}$ (arithmetical mean $470 \mathrm{~mm}$ ) on plot C (Dubová, 1996, 2001). On both plots, the highest values were measured in the fifth year after the cutting intervention. This year (1994) stands second regarding the precipitation amount over the last 20 years (Faško, Nieplová, 1995), with the winter precipitation totals being $289 \mathrm{~mm}$ (in January $219 \mathrm{~mm}$ ) on plot CC and $230 \mathrm{~mm}$ on C. This year (1994) was the second, the richest precipitation year in the period 1974 to 1994 (Faško, Nieplová, 1995). Precipitation totals in the winter of year 1994 reached $289 \mathrm{~mm}$ (in January $219 \mathrm{~mm}$ ) on plot CC and $230 \mathrm{~mm}$ on C. The beech crowns in the stand intercepted precipitation. Comparing the mean annual values of precipitation totals (arithmetical mean) over the 12-year study period, we can see a significant difference showing evidence for a noticeable (almost 30\%) interception of precipitation water in the beech forest stand. The values of precipitation totals $(\mathrm{mm})$ on the BEES study plot series with 
scaled density demonstrate an increase in the overall interception of atmospheric precipitation 5 (and 10) years after the intervention (1989) with the following values on particular plots: 9.4 (10.2)\% on HI, 23.6 (26.2)\% on MI, 35.1 (35.4)\% on LI and 36.5\% on C (Dubová, 1996, 2001; Tužinský et al., 2011).

The concentration values (weighted means) serving for assessment of sodium deposition were calculated for separate years (December-November) and seasons: winter (DecemberFebruary), spring (March-May), summer (June-August) and autumn (September-November). The basic statistical characteristics were derived by descriptive statistics, graphical representation was used for the dynamics and linear trend for sodium concentration and deposition. The coefficients of linear regression equations $(a, b)$, coefficient of reliability $\left(R^{2}\right)$ and regression coefficient $(\mathrm{R})$ for the seasons and year are summarised in Table 1 (sodium concentration) and Table 2 (sodium deposition). The histograms illustrate the frequency of sodium concentration and deposition on both plots. The most frequent value of annual sodium concentration recorded on CC was about $0.20 \mathrm{mg} \mathrm{l}^{-1}(\mathrm{n}=7)$, on C about $0.26 \mathrm{mg} \mathrm{l}^{-1}(\mathrm{n}=7)$. The most frequent values of annual sodium deposition on CC were two: $0.9 \mathrm{~kg}(\mathrm{n}=4)$ and $>1.4 \mathrm{~kg} \mathrm{Na}^{+} \mathrm{ha}^{-1}$ year $^{-1}(\mathrm{n}=$ 4). The value of this variable in the original forest stand was about $1.3 \mathrm{~kg} \mathrm{Na}^{+} \mathrm{ha}^{-1} \operatorname{year}^{-1}(\mathrm{n}=6)$.

T a b l e 1. Coefficients $(\mathrm{a}, \mathrm{b})$ of linear regression equation, coefficient of reliability $\left(\mathrm{R}^{2}\right)$ and regression coefficient (R) for sodium concentration.

\begin{tabular}{|c|cccc|cccc|}
\hline \multirow{2}{*}{ Period } & \multicolumn{4}{|c|}{ Clear-cut plot (CC) } & \multicolumn{4}{c|}{ Control plot (C) } \\
\cline { 2 - 9 } & $\mathrm{a}$ & $\mathrm{b}$ & $\mathrm{R}^{2}$ & $\mathrm{R}$ & $\mathrm{a}$ & $\mathrm{b}$ & $\mathrm{R}^{2}$ & $\mathrm{R}$ \\
\hline Winter & 0.1583 & 0.0023 & 0.0087 & 0.0933 & 0.2168 & 0.0018 & 0.0038 & 0.0616 \\
Spring & 0.1465 & 0.0060 & 0.0391 & 0.1977 & 0.2997 & 0.0091 & 0.0328 & 0.1811 \\
Summer & 0.1902 & 0.0091 & 0.1487 & 0.3856 & 0.2773 & 0.0119 & 0.1098 & 0.3314 \\
Autumn & 0.2279 & 0.0019 & 0.0025 & 0.0500 & 0.2611 & 0.0104 & 0.1712 & 0.4138 \\
Year & 0.1827 & 0.0035 & 0.0460 & 0.2145 & 0.2685 & 0.0118 & 0.3660 & 0.6050 \\
\hline
\end{tabular}

$\mathrm{T}$ a b l e 2. Coefficients $(\mathrm{a}, \mathrm{b})$ of linear regression equation, coefficient of reliability $\left(\mathrm{R}^{2}\right)$ and regression coefficient (R) for sodium deposition.

\begin{tabular}{|c|cccc|cccc|}
\hline \multirow{2}{*}{ Period } & \multicolumn{4}{|c|}{ Clear-cut plot (CC) } & \multicolumn{4}{c|}{ Control plot (C) } \\
\cline { 2 - 9 } & $\mathrm{a}$ & $\mathrm{b}$ & $\mathrm{R}^{2}$ & $\mathrm{R}$ & $\mathrm{a}$ & $\mathrm{b}$ & $\mathrm{R}^{2}$ & $\mathrm{R}$ \\
\hline Winter & 0.3038 & 0.0140 & 0.0390 & 0.1975 & 0.2960 & 0.0105 & 0.0337 & 0.1836 \\
Spring & 0.2199 & 0.0052 & 0.0233 & 0.1526 & 0.2449 & 0.0057 & 0.0637 & 0.2524 \\
Summer & 0.3755 & 0.0232 & 0.1804 & 0.4247 & 0.3135 & 0.0190 & 0.2077 & 0.4557 \\
Autumn & 0.8015 & 0.0515 & 0.3309 & 0.5752 & 0.4561 & 0.0272 & 0.2806 & 0.5297 \\
Year & 1.7007 & 0.0836 & 0.3361 & 0.5797 & 1.3107 & 0.0623 & 0.3148 & 0.5611 \\
\hline
\end{tabular}

The range of annual sodium concentration was $0.07-0.27 \mathrm{mg} \mathrm{l}^{-1}$ (CC) and $0.07-0.35 \mathrm{mg}$ $\mathrm{l}^{-1}(\mathrm{C})$. Both plots manifested decreasing trends for this variable (Fig. 2). The decrease on CC was slower, which resulted in crossing the trend lines of the two plots in the 10th year. In this way, the natural regeneration and growth of the beech stand on the study plots 10-12 years after the silvicultural intervention have been demonstrated. Both the original stand $(\mathrm{C})$ and the $\mathrm{CC}$ exhibited forest cover with varying density. 


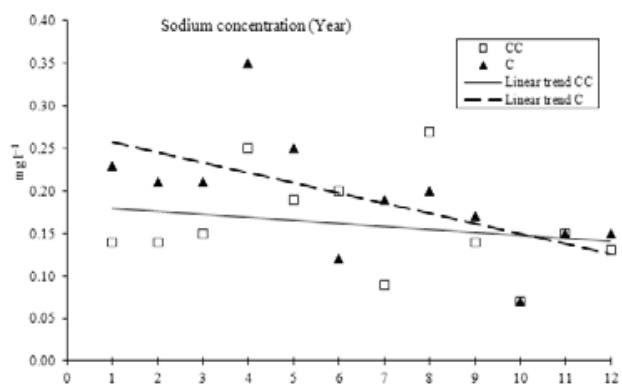

Fig. 2. Annual sodium concentration (weighted means, $\mathrm{mg} \mathrm{l}^{-1}$ ) and trends on BEES plots over 12-year study period.

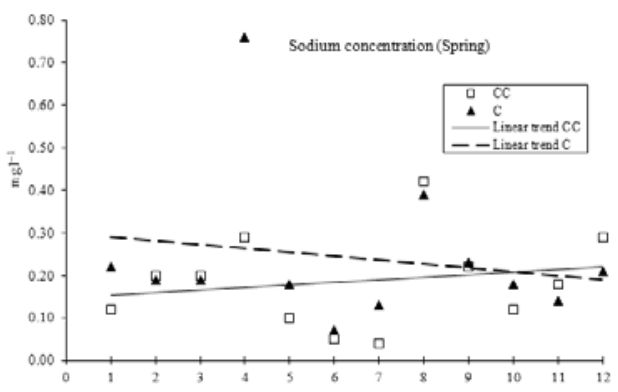

Fig. 4. Sodium concentration in spring season (weighted means, $\mathrm{mg} \mathrm{l}^{-1}$ ) and trends on BEES plots over 12-year study period.

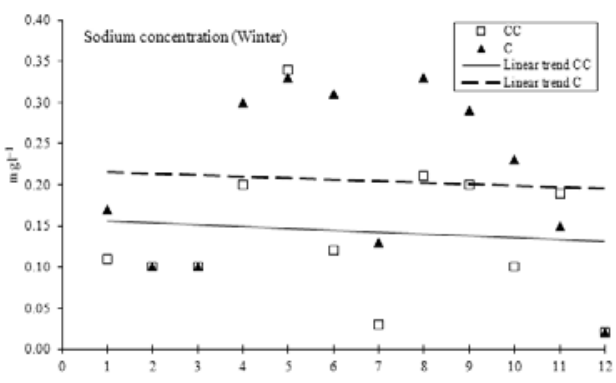

Fig. 3. Sodium concentration in winter season (weighted means, $\mathrm{mg} \mathrm{l}^{-1}$ ) and trends on BEES plots over 12-year study period.

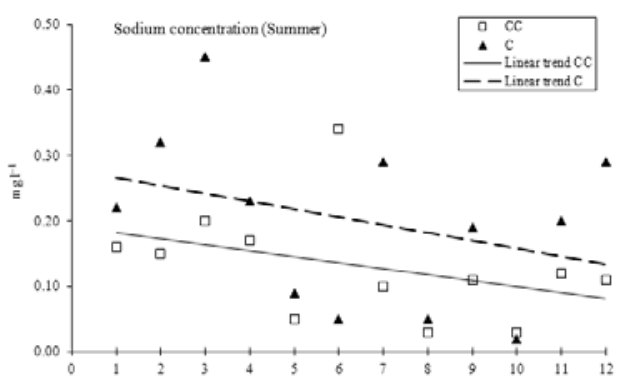

Fig. 5. Sodium concentration in summer season (weighted means, $\mathrm{mg} \mathrm{l}^{-1}$ ) and trends on BEES plots over 12-year study period.

The sodium concentration trends show differences between the seasons. The winter, summer and autumnal trends were decreasing on both plots, with negatives slopes of linear regression lines $(b)$ (Table 1$)$. A moderate decrease $(b=-0.0091)$ was also observed on $C$. The only exception was the trend on CC with a very small positive $b$ value of 0.0060 (Table 1 ). The winter and summer sodium concentrations on the two plots show similar trends. The winter values ranged from 0.02 to $0.34 \mathrm{mg} \mathrm{l}^{-1}$ (CC), and to $0.33 \mathrm{mg} \mathrm{l}^{-1}$ on C (Fig. 3). In summer, it was from 0.03 to $0.34 \mathrm{mg} \mathrm{l}^{-1}$ (CC) and from 0.02 to $0.45 \mathrm{mg} \mathrm{l}^{-1}$ on $\mathrm{C}$ (Fig. 5). The spring sodium concentration on both plots was somewhat higher than in the other seasons: from 0.04 to $0.42 \mathrm{mg} \mathrm{l}^{-1}$ (CC), and from 0.07 to $0.76 \mathrm{mg} \mathrm{l}^{-1}(\mathrm{C})$. In spring, there may occur leaching of young beech leaves very sensitive to leaching because of their thin, not completely developed cuticle (Van Ek, Draaijers, 1994). The spring trends are very similar to the annual trends, and a strong convergence was observed 10 years after the cutting intervention (Fig. 4). The trend of autumnal sodium concentration was different from the dynamics in the other seasons (Fig. 6). The higher sodium concentration in the sixth $\left(0.42 \mathrm{mg} \mathrm{l}^{-1}\right)$ and the eighth year $\left(0.50 \mathrm{mg} \mathrm{l}^{-1}\right)$ influenced the trend on CC. The autumnal sodium concentration in the study period ranged from 0.06 to $0.50 \mathrm{mg} \mathrm{l}^{-1}$ (CC) and from 0.08 to $0.36 \mathrm{mg} \mathrm{l}^{-1}(\mathrm{C})$. 
The mean annual sodium concentration $(\mathrm{n}=12)$, representing $0.16 \mathrm{mg} \mathrm{l}^{-1}(\mathrm{CC})$ and $0.19 \mathrm{mg}$ $\mathrm{l}^{-1}(\mathrm{C})$ have also been evaluated. These values may be considered as the background values. The seasonal sodium concentration on CC compared to $\mathrm{C}$ is also lower in winter, spring and summer. On the other hand, the autumnal values are lower in the throughfall (forest stand). The two plots manifested only small differences in the mean annual and seasonal concentrations $\left(0.03-0.07 \mathrm{mg} \mathrm{l}^{-1}\right)$. The sodium concentration in the throughfall at BEES was the lowest from all the base cations, ranked as follows: potassium, calcium, magnesium and sodium.

The lowest and the highest values of annual sodium deposition over the 12-year study period determined the deposition range on $\mathrm{CC}$ and $\mathrm{C}$ as 0.37 and $1.96 \mathrm{~kg}$ and as 0.25 and $1.82 \mathrm{~kg} \mathrm{Na}^{+} \mathrm{ha}^{-1}$ year $^{-1}$. On both plots, the highest sodium deposition values were obtained in the fifth study year - the most abundant in precipitation. The lowest values were recorded on $\mathrm{CC}$ in the $10^{\text {th }}$ year and on $\mathrm{C}$ in the $8^{\text {th }}$ year after the silvicultural intervention. The dynamics and trend of annual sodium deposition are given in Fig. 7. The trend is decreasing on both plots, which is evident from negative slope values (b) in the corresponding linear regression equations (Table 2). The decreasing trend of deposition in the completely closed stand was also accelerated by the decreasing trend in precipitation totals in the period discussed. The trends show that the annual amounts of sodium deposition on the two plots converge. Similar trends were also found for annual deposition of potassium (Dubová, Bublinec, 2006). These facts demonstrate that 10 years after the intervention, the original beech forest stand (control plot) and CC with developing stand cover exhibit changes in their density and structure. The regenerating beech stand on the former clear-cut plot has grown and reached the same density as the stand in rotation maturity on the control plot (Bublinec, Dubová, 2011).

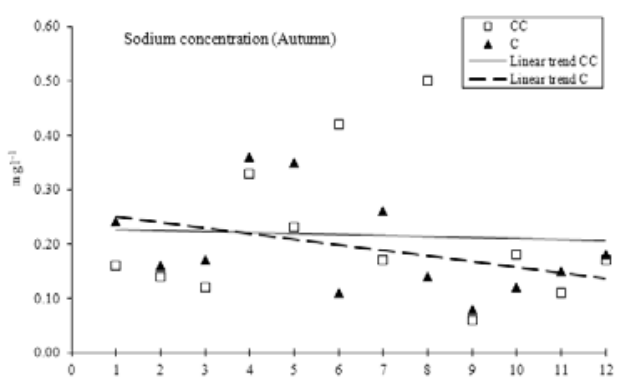

Fig. 6. Sodium concentration in autumnal season (weighted means, mg 1-1) and trends on BEES plots over 12year study period.

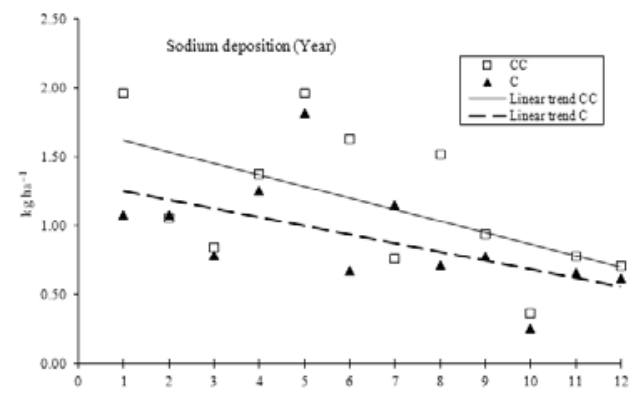

Fig. 7. Annual sodium deposition $\left(\mathrm{kg} \mathrm{ha}^{-1}\right.$ year $\left.{ }^{-1}\right)$ and trends on BEES plots over 12-year study period.

The minimum seasonal sodium deposition in winter was $0.03 \mathrm{~kg}$ on both plots. The maximum values were $0.97 \mathrm{~kg}(\mathrm{CC})$ and $0.75 \mathrm{~kg} \mathrm{Na}^{+} \mathrm{ha}^{-1}$ on control plot. On both plots, the values were very low and very similar (Fig. 8). The only exception was the deposition in the fifth evaluated year higher than in the other years. On the other hand, these winter deposition values allow us to exclude sodium sources, either natural or anthropogenic, in the BEES ecosystem. The minimum sodium deposition values in spring were $0.11 \mathrm{~kg}(\mathrm{CC})$ and $0.08 \mathrm{~kg} \mathrm{Na}^{+} \mathrm{ha}^{-1}$ (C). The maximum values were $0.43 \mathrm{~kg}$ (CC) and $0.33 \mathrm{~kg} \mathrm{Na}^{+} \mathrm{ha}^{-1}$ (C). The 


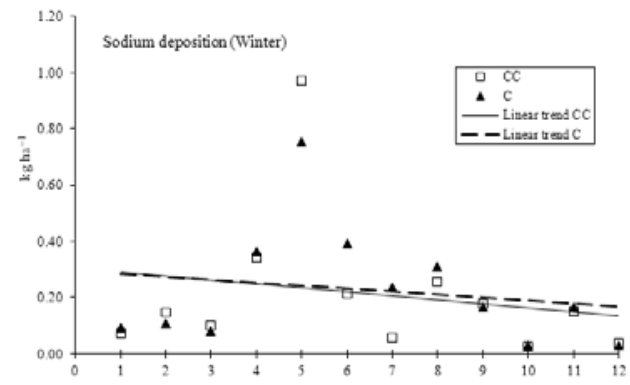

Fig. 8. Sodium deposition in winter season (kg ha-1) and trends on BEES plots over 12-year study period.

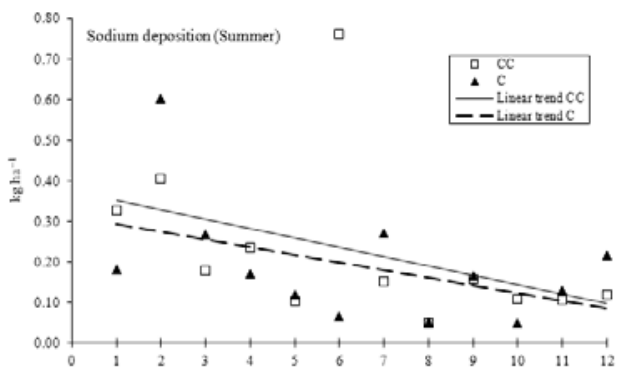

Fig. 10. Sodium deposition in summer season $\left(\mathrm{kg} \mathrm{ha}^{-1}\right)$ and trends on BEES plots over 12-year study period.

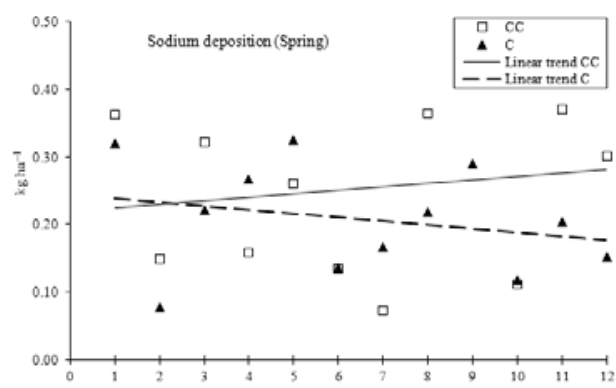

Fig. 9. Sodium deposition in spring season $\left(\mathrm{kg} \mathrm{ha}^{-1}\right)$ and trends on BEES plots over 12-year study period.

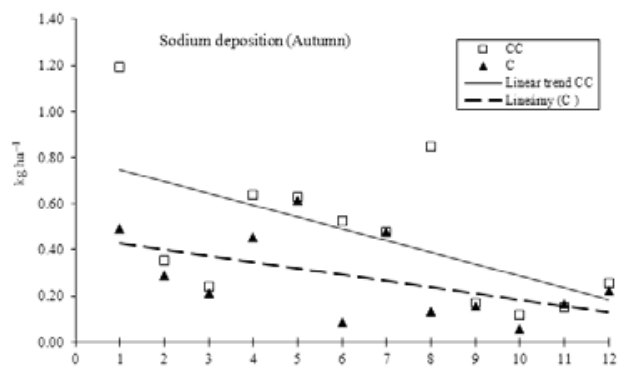

Fig. 11. Sodium deposition in autumnal season ( $\left.\mathrm{kg} \mathrm{ha}^{-1}\right)$ and trends on BEES plots over 12-year study period.

spring sodium deposition values are somewhat scattered, being higher on CC than on $\mathrm{C}$ in most years. A distinct increase in deposition on CC could be detected since the eighth year from the cutting intervention (Fig. 9). The slope of linear regression coefficient is positive (b $=0.0025)$. While the trend on $\mathrm{C}$ is decreasing $(\mathrm{b}=-0.0570)$, the opposite holds for CC. The spring pattern clearly reflects the presence of natural regeneration and growing beech stand which is getting more and more closed and changing its density. Young spring beech leaves are covered with a thin, not fully developed cuticle, and as such, they are prone to leaching (Van Ek, Draaijers, 1994). In the beech natural regeneration on CC, a rise in sodium deposition was manifested in 8-12 years after the intervention. Similar to winter, the summer sodium deposition also exhibited decreasing trends on both plots (Fig. 10). The values for the two plots were similar, ranging from $0.05 \mathrm{~kg}$ to $0.76 \mathrm{~kg}(\mathrm{CC})$ and to $0.60 \mathrm{~kg} \mathrm{Na}^{+} \mathrm{ha}^{-1}(\mathrm{C})$. The autumnal sodium deposition values manifested certain distinctive differences between the plots (Fig. 11). The autumnal values of linear regression coefficients $(\mathrm{a}, \mathrm{b})$ as well as $\mathrm{R}^{2}$ and $\mathrm{R}$ values were higher than the corresponding values for the other seasons (Table 2 ). The autumnal deposition range over the study period was from 0.12 to $1.19 \mathrm{~kg} \mathrm{Na}^{+} \mathrm{ha}^{-1}$ (CC) and from 0.06 to $0.62 \mathrm{~kg} \mathrm{Na}^{+} \mathrm{ha}^{-1}(\mathrm{C})$. The trends and amounts of deposition exhibit differences between the seasons. The winter and summer deposition values on the two plots are similar and low, the trends decreasing. For the spring season, the sodium deposition on CC shows an 
increase, representing the only case of positive value of the coefficient $b(0.0250)$ in the linear regression equation (Table 2). On plot $\mathrm{C}$, we can see a slight drop in the trend.

The mean annual sodium deposition across the study period was $1.2 \mathrm{~kg}(\mathrm{CC})$ and $0.9 \mathrm{~kg}$ $\mathrm{ha}^{-1}$ year $^{-1}(\mathrm{C})$. The winter and summer deposition was the same for both plots $\left(0.2 \mathrm{~kg} \mathrm{Na} \mathrm{Na}^{+}\right.$ $\left.\mathrm{ha}^{-1}\right)$. A moderate increase was recorded on CC in the spring $(0.3 \mathrm{~kg})$ and autumn $\left(0.5 \mathrm{~kg} \mathrm{ha}^{-1}\right)$, and on $\mathrm{C}$ in autumn $\left(0.3 \mathrm{~kg} \mathrm{Na}^{+} \mathrm{ha}^{-1}\right)$. The mean sodium concentration in autumn on $\mathrm{CC}$ was higher than on $\mathrm{C}$. The autumnal sodium deposition represents the maximum among the years seasons.

The ratio between the deposition in the throughfall and in clear cut has been given the name of crown impact coefficient (CIC). This parameter was calculated from sodium deposition on control plot and on clear-cut plot (C:CC) in the beech stand. The mean CIC value over the 12-year study period ranged from 0.6 (spring and autumn) to 1.0 (winter and summer), with a mean annual value of 0.8 . We can see that the sodium amount (mean annual value) delivered in the throughfall to the forest soil in the original forest stand (control plot) was lower than the sodium amount brought by atmospheric precipitation on the soil surface on clear-cut plot. This may indicate some sodium ion uptake by beech leaf surface. The mean annual value obtained at the BEES for potassium ions $(\mathrm{CIC}=2.0)$ is higher than for sodium. Potassium is a very mobile element. By leaching, it can easily release its physical and chemical bonds with the surface of as well as inside plant vegetation organs (Dubová, Bublinec, 2006).

Cappelatto and Peters (1995), conducting experiments for exploring interactions of sodium and chloride ions with the leaf surface in oak (Quercus robur L.), observed that chlorides were inert in this interaction. Contrarily, sodium ions tended to adsorb on the leaf surface and/or absorb by tissues inside the leaf (Ræbild, 1998). Several experiments focused on intensity of retention of aerosols on plant surface demonstrated that the intensity of particles trapping on the leaf surface may range from 10 to $90 \%$, in dependence on the plant species, probably due to differences in the leaf microstructure. Leaching is associated with some losses affected by the leaf physiology and by chemical processes taking place on the leaf surface. The dynamics and molecular mechanisms driving the uptake of potassium as an essential nutrient and sodium ions are tightly interlocked, hence sodium can easily replace potassium in the plant cells. In such a way, physiological processes may be restricted. In general, it holds that the absorption of a specific ion is reduced when the concentration of another ion in the external environment rises. For example, sodium and potassium ions tend to be efficient inhibitors for all the other ions (Reinap et al., 2010). The leaching of potassium peaks at the beginning and towards the end of growing season, because young spring leaves covered with thin, not full developed cuticle, as well as autumnal ageing leaves are especially susceptible to leaching (Van Ek, Draaijers, 1994). Leaching with precipitation water with low sodium concentration can cause only small sodium losses to forest stands (Reinap et al., 2010). The mechanism of ion exchange between $\mathrm{K}^{+}$and $\mathrm{Na}^{+}$may be the underlying cause of lower sodium deposition in the throughfall on control plot than on clear-cut plot. This fact can also explain why CIC values calculated from the sodium deposition in the beech ecosystem over the 12-year study period were lower in spring (0.7) and autumn (0.6).

In high concentration, sodium ion is toxic for most plans. Its toxicity is multifactorial, encompassing osmotic stress, inhibition of vital enzymes and competition with potassium ion 
(Bublinec, 1984, 1991a,b,c,d,e, 1997; Mäser et al., 2002; Ræbild, 1998). In this context, the low sodium concentration and deposition values determined in precipitation and throughfall at BEES indicate that the beech forest at the site may be considered as ecologically clean, not affected by sodium pollution of anthropogenic origin.

\section{Conclusion}

Sodium, as an alkaline component of precipitation water, neutralises acid environment in forest ecosystems and alleviates the effects of acid precipitation. Samples of precipitation and throughfall for the evaluation of sodium concentration and deposition were taken on two plots (CC - clear cut and C - control) of the BEES in each year and season across 12 years after cutting. The aim was to assess the amount of sodium entering the beech stand and reaching the forest soil surface.

Among the base ions $\left(\mathrm{Ca}^{2+}, \mathrm{Mg}^{2+}, \mathrm{K}^{+}\right)$, sodium displayed the lowest concentration in precipitation. The annual concentration of sodium over the study period ranged from 0.07 to 0.27 $\mathrm{mg} \mathrm{l}^{-1}$ (CC), or to $0.35 \mathrm{mg} \mathrm{l}^{-1}(\mathrm{C})$. The mean annual concentration on CC $\left(0.16 \mathrm{mg} \mathrm{l}^{-1}\right)$ was lower compared to $\mathrm{C}\left(0.19 \mathrm{mg} \mathrm{l}^{-1}\right)$. The trends in annual sodium concentrations on the two plots are very similar to the spring trends on these plots. In both cases, the trends on the two plots converged together in the 10th year after the cutting treatment. The concentration values converted to deposition values show that the average sodium amount transported to the forest ground in the throughfall in the original beech forest stand (control plot) was less $(0.9 \mathrm{~kg})$ than that delivered with rainfall on CC $\left(1.2 \mathrm{~kg} \mathrm{Na}^{+} \mathrm{ha}^{-1} \mathrm{year}^{-1}\right)$. The cause may be the considerable interception in the forest stand and possible sodium uptake by beech leaves. Sodium ions have a tendency to adsorb on the leaf surface and/or absorb into the leaf tissues. Sodium can easily replace potassium in plant cells. It also follows that the mechanism of ion exchange between $\mathrm{K}^{+}$ and $\mathrm{Na}^{+}$may help to explain the lower sodium deposition in the forest stand (in throughfall) compared to CC.

The spring period is characterised by somewhat higher sodium concentration on both plots compared to the other seasons: from 0.04 to $0.42 \mathrm{mg} \mathrm{l}^{-1}$ (CC) and from 0.07 to $0.76 \mathrm{mg} \mathrm{l}^{-1}$ (C). The young spring beech leaves are covered with a thin, not completely developed cuticle, and as such, they are sensitive to leaching. The spring deposition on our study plots was from 0.11 to $0.43 \mathrm{~kg}(\mathrm{CC})$, and from 0.08 to $0.33 \mathrm{~kg} \mathrm{Na}^{+} \mathrm{ha}^{-1}(\mathrm{C})$. The spring trends on $\mathrm{C}$, both in sodium concentration and deposition, were decreasing. The only case when there trends were rising was plot CC in spring. The spring season clearly reflected the fact that 10-12 years after the cutting, natural regeneration and growth of beech is present not only on control plot but also on clear-cut plot - progressively overgrown and changing its density. The winter and summer were characterised by similar deposition values and decreasing trends on both plots. The winter deposition values ranged from 0.03 (both plots) to $0.97 \mathrm{~kg}(\mathrm{CC})$, and $0.75 \mathrm{~kg} \mathrm{Na}^{+} \mathrm{ha}^{-1}(\mathrm{C})$, the summer ones from 0.05 (both plots) to $0.76 \mathrm{~kg}$ (CC), and to $0.60 \mathrm{~kg} \mathrm{Na}^{+} \mathrm{ha}^{-1}(\mathrm{C})$. The autumnal differences between the plots were more distinct: 0.12 to $1.19 \mathrm{~kg}(\mathrm{CC})$ and 0.06 to $0.62 \mathrm{~kg} \mathrm{Na}^{+}$ $\mathrm{ha}^{-1}(\mathrm{C})$.

The ratio of sodium deposition on control and clear-cut plot (C:CC) is called crown impact coefficient (CIC). The average CIC values over the 12 -year study period were 0.6 (spring, au- 
tumn), 1.0 (winter, summer) and 0.8 (annual). This means that the sodium amount delivered with throughfall to the forest soil surface in the stand was lower than the amount fallen with rain and snow on plot CC. The mean annual CIC value for sodium was lower $(0.8)$ than for potassium (2.0).

The experimentally obtained sodium deposition values suggest that the beech forest at the BEES is ecologically clean. There have been detected no effects of sodium sources, either natural or anthropogenic. All the obtained values were low and can be considered as the background ones.

\section{Acknowledgements}

This paper has been written in frame of the grant project VEGA No. 1/0421/14, participated by the author, working at Institute of Forest Ecology SAS in Zvolen. I would like to express my thanks to the grant agency for supporting my work and to D. Kúdelová for preparing the English text.

\section{References}

Barna, M. (2004). Adaptation of Europe beech (Fagus sylvatica L.) to different ecological conditions leaf size variation. Pol. J. Ecol., 52, 35-45.

Bublinec, E. (1984). Edaphic factors determining the growth of woody plants (in Slovak). In Creation and protection of greenery in urban landscape (pp. 167-174). Nitra.

Bublinec, E. \& Dubová M. (1989). Annual dynamics of precipitation acidity in beech and spruce ecosystems (in Slovak). Lesnícky Časopis, 35(6), 463-475.

Bublinec, E. (1991a). Acid precipitation and reforestation coniferous forests. In IUFRO workshop on monitoring air pollution impact on permanent sample plots, data processing and results interpretation (pp. 192-194). Prachatice.

Bublinec, E. (1991b). Urban soils (in Slovak). In J. Supuka et al. (Eds.), Ecological principles of planning and conservation of greenery (pp. 45-48). Bratislava: Veda, vydavatel'stvo SAV.

Bublinec, E. (1991c). Degrading factors in urban soils (in Slovak). In J. Supuka et al. (Eds.), Ecological principles of planning and conservation of greenery (pp. 48-51) Bratislava: Veda, vydavatel'stvo SAV.

Bublinec, E. (1991d). Eco-edaphic criteria for planning of greenery (in Slovak). In J. Supuka et al. (Eds.), Ecological principles of planning and conservation of greenery (pp. 51-57). Bratislava: Veda, vydavatelstvo SAV.

Bublinec, E. (1991e). Decontamination of urban soils (in Slovak). In J. Supuka et al. (Eds.), Ecological principles of planning and conservation of greenery (pp. 57-59). Bratislava: Veda, vydavatel'stvo SAV.

Bublinec, E. (1992). The content of biogenic elements in forest treespecies (in Slovak). Lesnícky Časopis, 38(4), 365-375.

Bublinec, E. (1993). Influence of regeneration cutting applied in a spruce ecosystem on sulphate deposition in the throughfall of this ecosystem (in Slovak). Lesnicky Časopis, 39(6), 525-530.

Bublinec, E. \& Dubová M. (1993). Annual dynamics of calcium deposition and its ecological consequences for forest ecosystem (in Slovak). Lesnícky Časopis, 39(5), 405-413.

Bublinec, E. (1994). Concentration, accumulation and cycles of elements in a beech and a spruce ecosystem (in Slovak). Acta Dendrobiologica. Bratislava: Veda, vydavatel'stvo SAV.

Bublinec, E. \& Kukla J. (1994). Natural edaphic-ecological conditions and influence of polluted air on state of forest soils. In State of ecological research on soil science and land use in Slovak Republic and in Austria. Mitteilungen der Osterreichischen Bodenkundlichen Gesellschaft, 50, 31-42.

Bublinec, E. (1996). Impairment and protection of ecological-production properties of soils - a challenge for the future (in Slovak). Proceedings from the scientific conference (pp. 161-168). Bratislava: VÚPOP.

Bublinec, E. \& Mihálik A. (1997). Content of macro- and microelements in forest soils of the National Park Pieniny (in Slovak). In Monographic studies on the national parks. The Report of the Management of National Parks of the SR, $1,12-31$.

Bublinec, E. (1997). Endangering and protection of soil production functions (in Slovak). In Půdní systémy a antropická činnost (pp. 47-49). ČPS-ISSS.

Bublinec, E., Mihálik, A. \& Slávik D. (1998). Comparative studies on chemical composition of precipitation and surface 
water in the western part of the BR Polana Mts in years 1994 and 1995 (in Slovak). In Atmospheric deposition and eco-physiological processes in ecosystems (pp. 83-84). Proceedings of the papers from the international workshop. Zvolen: TU.

Bublinec, E. (1999). The sources of alien substances entering the forest ecosystems in the SR (in Slovak). Zprávy Lesnického Výskumu, 4, 31-35.

Bublinec, E., Baculáková, E. \& Babicová A. (2005). Anthropogenic input of substances into bio-geochemical cycles and their impacts on the biota (in Slovak). In The biology in school today and tomorrow (pp. 6-15). Ružomberok: PF KU.

Bublinec, E. \& Dubová M. (2011). Precipitation chemistry (in Slovak). In M. Barna, J. Kulfan \& E. Bublinec (Eds.), Beech and beech ecosystems of Slovakia (pp. 591-620). Bratislava: Veda, vydavatelstvo SAV.

Cappelatto, R. \& Peters N.E. (1995). Dry deposition and canopy leaching rates in deciduous and coniferous forests of the Georgia Piedmont: an assessment of the regression model. J. Hydrol., 169, 131-150. DOI: 10.1016/00221694(94)02653-S.

Dubová, M. (1996). Precipitation and throughfall at the Beech Experimental Ecological Site of the Kremnické vrchy Mts (in Slovak). Final Report. Zvolen: Ústav ekológie lesa SAV.

Dubová, M. (2001). Precipitation and throughfall at the Beech Experimental Ecological Site of the Kremnické vrchy Mts (in Slovak). Final Report. Zvolen: Ústav ekológie lesa SAV.

Dubová, M. \& Bublinec E. (2002). Dynamics and input of magnesium transported by precipitation in a beech ecosystem as a component of biogeochemical cycle of this ecosystem. Ekológia (Bratislava), 21(Suppl. 2), 3-12.

Dubová, M. \& Bublinec E. (2006). Potassium in a beech ecosystem in the Kremnické vrchy Mts (in Slovak). In O. Kontrišová, A. Marušková \& J. Válka (Eds), Monitoring and assessment of the condition of the living environment (september 2005) (pp. 99-105). Zvolen: FEE TU, ÚEL SAV.

Faško, P. \& Nieplová E. (1995). Climatic evaluation of air temperature and atmospheric pricipitation in 1994 (in Slovak). Bulletin of SMS SAV, 6(3), 9-12.

Janík, R., Bublinec, E. \& Dubová M. (2011). Impact of regeneration cutting on sulphate concentration and amount in throughfall water in conditions of submontane beech forests in the Western Carpathians Mts. Folia Oecologica, 35(2), 156-161.

Kellerová, D. \& Dubová M. (2002). The hydrogen ion deposition and proton load of the Kremnické vrchy Mts. Ekológia (Bratislava), 21, 423-430.

Lovett, G.M., Lindberg, S.E., Richter, D.D. \& Johnson D.W. (1985). The effects of acidic composition on cation leaching from deciduous forest canopy. Can. J. For. Res., 15, 1055-1066. DOI: 10.1139/x85-171.

Noskovič, J. (2010). The Nature Reserve Žitavský luh. Abiotic components (in Slovak). Nitra: SPU.

Nováček, P. (1986). Basic phyto-chemical concepts in botany (in Slovak). Olomouc: Univerzita Palackého.

Parker, G.G. (1983). Throughfall and stemflow in the forest nutrient cycle. Adv. Ecol. Res., 13, 57-133. DOI: 10.1016/ S0065-2504(08)60108-7.

Polkowska, Ż., Astel, A., Walna, B., Małek, S., Mędrzycka, K., Górecki, T., Siepak, J. \& Namieśnik J. (2005). Chemometric analysis of rainwater and throughfall at several sites in Poland. Atmos. Environ., 39, 837-855. DOI: 10.1016/j. atmosenv.2004.10.026.

Ræbild, A. (1998). Physiological responses of spuce (Picea) genotypes to simulated aerial Borne salt. PhD Thesis, Department of Economics and Natural Resources. Arboretum. The Royal Veterinary and Agricultural Univesity.

Ragsdale, H.L., Lindberg, S.E., Lovett, G.M. \& Schaeffer D.A. (1992). Atmospheric deposition and throughfall fluxes of base cations. In D.W. Johnson \& S.E. Lindberg (Eds), Atmospheric deposition and forest nutrient cycling (pp. 235-253). Ecological Studies 91. New York: Springer-Verlag.

Reinap, A., Wiman, B.L.B., Gunnarsson, S. \& Svenning B. (2010). Dry deposition of $\mathrm{NaCl}$ aerosols: theory and method for a modified leaf-washing technique. Atmos. Meas. Tech. Discuss., 3, 3851-3876. DOI:10.5194/amtd-3-3851-2010.

Remy, H., 1961: Inorganic chemistry (in Czech). I. part. Praha: Státní nakladatelství technické literatury.

Thimonier, A., Schmitt, M., Waldner, P. \& Schleppi P. (2007). Canopy leaching and the use of $\mathrm{Na} / \mathrm{Cl}$ ratio in validating chemical analyses of throughfall samples. Expert panel on Deposition. Eger, 14 September 2007.

Thimonier, A., Schmitt, M., Waldner, P. \& Schleppi P. (2008). Seasonality of the Na/Cl ratio in precipitation and implications of canopy leaching in validation chemical analyses of throughfall samples. Atmos. Environ., 42: 9106-9117. DOI: 10.1016/j.atmosenv.2008.09.007.

Tužinský, L., Gregor, J., Pichler, V., Střelcová, K., Dubová, M. \& Janík R. (2011): Water cycle (in Slovak). In M. Barna, J. Kulfan \& E. Bublinec (Eds.), Beech and beech ecosystems of Slovakia (pp. 103-120). Bratislava: Veda, vydavatelstvo SAV.

Van Ek, R. \& Draaijers G.P.J. (1994). Estimates od atmospheric deposition and canopy exchange for three common tree species in the Netherlands. Water, Air, Soil Pollut., 73, 61-82. DOI: 10.1007/BF00477976. 